Horizontal Learning in the High Middle Ages 


\section{Knowledge Communities}

This series focuses on innovative scholarship in the areas of intellectual history and the history of ideas, particularly as they relate to the communication of knowledge within and among diverse scholarly, literary, religious, and social communities across Western Europe. Interdisciplinary in nature, the series especially encourages new methodological outlooks that draw on the disciplines of philosophy, theology, musicology, anthropology, paleography, and codicology.

Knowledge Communities addresses the myriad ways in which knowledge was expressed and inculcated, not only focusing upon scholarly texts from the period but also emphasizing the importance of emotions, ritual, performance, images, and gestures as modalities that communicate and acculturate ideas. The series publishes cutting-edge work that explores the nexus between ideas, communities and individuals in medieval and early modern Europe.

Series Editors

Clare Monagle, Macquarie University

Mette Bruun, University of Copenhagen

Babette Hellemans, University of Groningen

Severin Kitanov, Salem State University

Alex Novikoff, Fordham University

Willemien Otten, University of Chicago Divinity School 


\title{
Horizontal Learning in the High Middle Ages
}

Peer-to-Peer Knowledge Transfer in Religious Communities

\author{
Edited by
}

Micol Long, Tjamke Snijders, and Steven Vanderputten 
Cover illustration: Detail of a bas-de-page scene of a group of three monks led forward by another monk (British Library Royal 10 E IV f. 222)

Cover design: Coördesign, Leiden

Typesetting: Crius Group, Hulshout

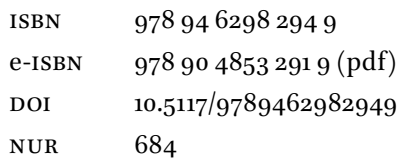

Creative Commons License CC BY NC (http://creativecommons.org/licenses/by-nc/3.o)

@ All authors / Amsterdam University Press B.V., Amsterdam 2019

Some rights reserved. Without limiting the rights under copyright reserved above, any part of this book may be reproduced, stored in or introduced into a retrieval system, or transmitted, in any form or by any means (electronic, mechanical, photocopying, recording or otherwise). 